\title{
Africa after apartheid: South Africa, race, and nation in Tanzania
}

\author{
Heike Becker
}

\section{Book reviews}

Africa after apartheid: South Africa, race, and nation in Tanzania, by Richard A. Schroeder, Bloomington, Indiana University Press, 2012, 248 pp., US\$25.00 (paperback), ISBN: 978-0-253-00600-4.

South African economic and political expansion into the African continent has been a controversial feature of the post-apartheid era. Now human geographer Richard Schroeder has taken up the matter in an ethnographic study based in Tanzania, a preferred destination for South African business. The country presents a particularly interesting example of the post-apartheid social, cultural and political dynamics of "South Africa in Africa" since Tanzania had been one of the apartheid regime's staunchest enemies. Schroeder starts off with observations of white South African expatriates he met in Tanzania; the book's core theme, however, is the country's and the wider African region's dilemma in an era that saw both the rise of neoliberalism and the fall of apartheid.

Schroeder shows that it is the Tanzanian response to the expanded South African presence in the region, rather than South African economics and politics as such, that is crucial to understanding the current dilemma. He is particularly interested in the "de-moral-isation" of the region's political economy (162), which has pitted those Tanzanians who "seek to uphold the moral legacies of Nyerere against those who have abandoned socialist precepts in the interests of pursuing private gain” (164).

The book opens with the observation that while the anti-apartheid struggle, its transnational dimensions and the ongoing politics of racial reconciliation in postapartheid South Africa have been the subjects of extensive academic and popular discussion, the rest of the African continent has been rather neglected in telling this tale. Schroeder, who has conducted fieldwork in West Africa and Tanzania, emphatically makes the point that,

from the perspective of observers situated elsewhere in Africa, it is clear that the phenomenon that was apartheid was never confined to South Africa's borders. To the contrary, its influence was, and is, felt across the [African] region ... Similarly, important elements of the post-apartheid transition 
- the dismantling of racially skewed social systems, the launching of efforts to reconcile historical animosities, the rebuilding of political and economic relationships - have also had far-reaching consequences for Africans living beyond South Africa's national borders. (1)

Chapter 1 recounts Tanzania's long involvement with the Southern African liberation struggles. Julius Nyerere, the country's first president, thus provided a "moral compass" (37), which profoundly shaped early Tanzanian nationhood. That the successors of the white racist regime in Pretoria, known in KiSwahili as makaburu [boers], were to fan out onto the continent, and that it was predominantly white South Africans who turned up in Tanzania, mobilised frontline memories as a symbolically significant political tool in the debate over national economic politics.

Schroeder details these developments in Chapters 2 and 3 that provide the context of the debate over neoliberal reforms in the increasingly "investor friendly" Tanzanian economy and how these reforms intersected with and were shaped by the inroads South Africans made into Tanzania, both as investors and as exporters. Schroeder presents the expansive national debate over Tanzania's neoliberal reforms and the key role South Africa played in their implementation through a detailed discussion of sectors such as breweries, tourism, telecommunications, retail grocery, banking, construction, energy and transportation. He shows that the debates did not remain on an economic policy level, however, but spread out to incorporate expansive controversies about social, cultural and political relations, and indeed questioned the shifts in "Tanzania's national character" (75) due to the growing South African presence as a constant reminder of the country's road to neoliberalism.

Chapter 4 is given to the mining of Tanzanite, the rare, blue gemstone that has been at the centre of battles between "artisanal" miners and the Tanzanian government that curtailed small- scale mining in favour of private corporate investors. Many of the miners who had found work in the tanzanite industry in the 1980s and 1990s had done so after having lost jobs through the structural adjustment and privatisation policies implemented by the post-Nyerere government, and mandated by the World Bank and International Monetary Fund. Schroeder shows that the act of selling off prized national assets such as the tanzanite deposits was widely seen as being immoral and unjust, and that - because of Tanzania's former militant anti-apartheid stance - it was particularly painful that the firm buying the mine in 1996 was run by white South Africans. Artisanal miners and their supporters objected to the measures initiated by the South Africanowned corporation and its backers in the Tanzanian government as "apartheid acts," hence in a distinctly moral economic sense (112).

Chapter 5 presents detailed personal life histories of white South Africans, six men and two women, who hailed from different parts of South Africa, were of different language backgrounds, and differed in terms of prior life and work experience, but had in common that they had opted to seek new opportunities in Africa. Through oral histories the chapter explores the reasons why they opted to stay in Africa, and how they viewed their new lives 
in Tanzania. Schroeder emphasises the diversity of the social locations occupied by the South Africans who moved to Tanzania. This challenges the one-dimensional stereotype that is attached to makaburu in Tanzanian popular discourse. He points out that the South Africans in Tanzania held sharply divergent and frequently contradictory attitudes with respect to racial and national identity, and their country's role in reshaping the region's economic geography. Yet, he argues, irrespective of their individual attitudes, "the experience and the legacy of apartheid reverberated strongly in their dealings with Tanzanians in the post-apartheid period" (115). While they initially feared that they might be "subject to some sort of reprisal for the sins of apartheid" (115), gradually most came to view their lives in Tanzania as an opportunity to rebuild their lives in a new setting.

Chapter 6 discusses mechanisms of inclusion and exclusion used to block racial and social "undesirables" (147) from certain spaces of the social sphere in Tanzania. The chapter draws on interviews with Tanzanians, South Africans and other expatriates. Much of it is about a South African-owned health club in a gated residential complex in Dar es Salaam. Schroeder demonstrates that although many expatriate whites [wazungu], including progressive South Africans, were seen as distancing themselves from racist practices, the stereotype of the South African makaburu remained and their increasing presence in the country "led to a spike of race consciousness across the board in Tanzania" (143).

This is an excellent study and an important book that demonstrates through painstaking ethnography that the politics of memory and forgetting are at the centre of shaping the new era of neoliberal economic agendas. The image that emerges from Schroeder's work is complex. His ethnographic research reveals that the trajectories of "Africa after apartheid" are largely about Tanzania's national ambivalence regarding the country's neoliberal politics in post-socialist transition. His final conclusion is worth quoting at some length:

South African investments in Tanzania have generated intense introspection on the part of many of my informants over cultural identity ... The class fractions competing for neocolonial ascendancy and control of the Tanzanian economy are themselves indelibly marked by race, ethnicity, and nationality. The growing South African presence has only served to heighten the visibility of all these divisions. (163)

It may be rather surprising that the promotion and active suppression of memories of Tanzania's determinedly anti-colonial, African socialism period may be just as significant, if not more, in this process than are the South African inroads themselves. These revelations, however, have become possible through long-term fieldwork. Schroeder conducted field site visits and extensive interviews with South African investors and employees working and living in Tanzania, as well as with Tanzanian activists, pastoralist leaders, traders, corporate entrepreneurs and civil servants (some retired). He much deserves to be lauded for such close-up ethnography during which he 
worked with a wide range of actors, listening carefully to proponents of wilful forgetting in the pursuit of neoliberal reforms, and to their opponents who resisted them in the memory of Nyerere. 